ISSN: 2224-0616

Int. J. Agril. Res. Innov. \&Tech. 5(2): 82-85, December, 2015 Available online at http:// www.ijarit.webs.com

\title{
SMALL SCALE INTEGRATED AGRICULTURE: A TOOL OF POVERTY ALLEVIATION, GENDER EQUALITY PROMOTION AND IMPROVING FOOD SECURITY AT HOUSEHOLD LEVEL IN COASTAL REGION OF BANGLADESH
}

\author{
M.R. Begum ${ }^{*}$, M.N. Islam2 ${ }^{2}$ M.S.I. Khan ${ }^{3}$, S. Islam² and M.A.I. Tapu' ${ }^{2}$
}

Received 30 October 2015, Revised 13 December 2015, Accepted 22 December 2015, Published online 31 December 2015

\begin{abstract}
In developing countries, small scale integrated agriculture acts as a tool for supplying the fast-growing human population with high-quality protein, additional income to poor and food security to household, especially women. This study was conducted in different SLOPBBangladesh project areas of Patuakhali, a coastal district of Bangladesh to observe the effect of small scale integrated agriculture on poverty alleviation, equality of gender promotion and food security at household level. After baseline survey with a structured questionnaire, a total of 583 women beneficiaries were selected from poor communities and given training and technical support on family poultry, aquaculture and homestead gardening from 2008 to 2012. Data of income were collected in every month and analyzed by one way ANOVA or F-test, used to test significant difference among the mean income of different years and one sample t-test, used to test the significance difference in percent (\%) of yearly increase income in different years and from baseline. It was postulated that, the number of income getting women grew in an upward trend along the advances of time, and average yearly income became significantly from baseline and rose to 246 , and $566.42 \%$ for family poultry and homestead gardening respectively. For all three activities, it was significantly climbed to $281.79 \%$, which brings better food and nutritional security in household, and the women were self-employed, empowered, and more esteemed to their family members as well as society than ever before.
\end{abstract}

Keywords: Small Scale Integrated Agriculture, Income, Women Empowerment, Food Security

\footnotetext{
${ }^{1}$ Department of Agricultural Economics and Social Sciences, Chittagong Veterinary and Animal Sciences University, Bangladesh; ${ }^{2}$ Empowerment of the Poor through Integrated Agriculture, SLOPB-Bangladesh; ${ }^{3}$ Department of Food Microbiology, Patuakhali Science and Technology University, Bangladesh.

*Corresponding author's email: rasustat@yahoo.com (M.R. Begum)
}

\section{Introduction}

History illustrates that different rates of poverty reduction over the past 40 years have been closely related to differences in agricultural performance - particularly the rate of growth of agricultural productivity (DFID, 2004). Poverty, measured by poverty line, a threshold level of income or expenditure, needed to meet food and non-food basic needs for a person to maintain a healthy and productive life (Hossain, 2004). Level of poverty in 2000 to be in the order of 50 per cent in contrast to 40 per cent derived on the basis of 1983 with roughly about $1 \%$ reduction per year (World Bank, 2002). Since three-fourths of the population, with over $40 \%$ are poor, still lives in rural areas in Bangladesh, and this poverty rate descending very slowly by one percent per year due to high inequality in the distribution of income for both rural and urban areas (Sen, 2001). For this purpose, it remains a predominantly rural problem, where agriculture is central to livelihoods and, a study said that, $67 \%$ in South Asia are at least partly engaged in agriculture (Maxwell, 2001). Therefore, any improvement in agriculture includes crop fisheries and livestock may raise rural incomes, which may exert a major impact on poverty (Warr, 2001). Moreso, agricultural development may be a prime mover of improving food security (DFID, 2004). Food security includes food availability and access, ensuring adequate diet of all members of household, achieved either by production or by purchase.

Recent household surveys shows that the consumption of cereals has reached a level much higher than the minimum nutritional requirement, there is a marginal deficit for tubers and vegetables and fish, but substantial deficits for pulses, oilseeds and livestock products. Thus, crop and agricultural diversification must be given priority in agricultural development strategy to achieve balanced nutrition (Hossain, 2004). For reaching, the Millennium Development Goal (MDG) of halving the proportion absolute poverty by 2015 would 
depend on growing agricultural productivity, which is to be considered as single most important determinant of economic growth and poverty reduction (DFID, 2004). Therefore, intervention on all three activities is required to increase income, maintain better food security, and self-employment and empowerment of women. As it was proven that, small scale integrated agriculture is accessible to the poorest of the poor. Considering the above facts, the study was undertaken to observe the effect of small scale integrated agriculture on household level regarding increased income, increased food production and security, and promotion of gender equality.

\section{Materials and Methods}

\section{Selection of target women}

A total of 583 women, single from each household, based on convenient sampling method, were selected from different areas where they have the less land and their family led their lives mainly depending of different daily nominal and low-income activities like minimum agricultural activities in coastal Patuakhali district of Bangladesh.

\section{Baseline survey}

A pre structured and pre tested questionnaire was used to conduct the baseline survey in terms of demographic, socio-economic status, and monthly income from each three target components of small scale agriculture viz. family poultry, aquaculture and homestead gardening.

\section{Training and information dissemination}

To increase their income, different activities like participatory needs assessment and planning, weekly group meetings, training on all three activities, create linkage with markets and continuous monitoring were done during the study period.

\section{Data collection}

Income of household from three main components of agriculture as family poultry, aquaculture and homestead gardening, after family consumption, considered as effects or result. The mount of income in BD taka was converted into Euro at the rate of 100 taka for 1 Euro. Data on income from three elements collected in every month from every beneficiary.

\section{Data analysis}

The measure of central location, average was used to calculate mean income in different years. One way analysis of variance (ANOVA) or F-test was used to compare means in different years income and $t$-test for increasing income from year to year and from baseline.

\section{Results}

Table 1 illustrates the household income from family poultry from baseline until 2011-2012. It was well mentioned that, after making up the family demand, the number of extra earning women increased from baseline 43.0 to 63.7, $60.0,69.9$ and $62.6 \%$ in the end successive years and, yearly income per household were highly significantly went up ( $\mathrm{F}=20.81$; $\mathrm{P}$ - value $<0.01)$ from baseline BD Tk. 614 (or 0.02 Euro/day) to 1543 (or 0.04 Euro/ day), 2148 (or 0.06 Euro/day), 2444 (0.07 Euro/day) and 2738 (0.075 Euro/day), whereas yearly increased income from baseline were significantly rose $(\mathrm{t}=$ 7.70; P-value <0.05) to 151.33, 249.84, 298.04 and $246 \%$ and, increasing from every preceding years were 151.3, 39.21, 13.78 and $12.03 \%$.

Table 1. Descriptive statistics of household income from family poultry

\begin{tabular}{lcccccc}
\hline & Base & $2008-09$ & $2009-10$ & $2010-11$ & $2011-12$ & P-value \\
\hline Mean & 614 & 1543 & 2148 & 2444 & 2738 & $* * *$ \\
$\mathrm{~N}(\%)$ & $250(42.9)$ & $352(63.7)$ & $344(60)$ & $384(69.9)$ & $358(62.6)$ & \\
Euro/ year & 6.14 & 15.43 & 21.84 & 24.44 & 27.38 & \\
Euro/ day & 0.017 & 0.042 & 0.06 & 0.067 & 0.075 & NS \\
\%yearly increase & & 151.3 & 39.21 & 13.78 & 12.03 & $* *$ \\
\%increase from baseline & & 151.3 & 249.84 & 298.04 & 246 & $*$ \\
\hline
\end{tabular}

**Significant at 5\% level; ***Significant at 1\%level; NS=Not significant; N=No. of women; 1 Euro = 100 Tk

Table 2. Descriptive statistics of household income from aquaculture

\begin{tabular}{lcccccc}
\hline & Base & $2008-09$ & $2009-10$ & $2010-11$ & $2011-12$ & P-value \\
\hline Mean & 1529 & 1575 & 2151 & 2714 & 3713 & *** \\
N(\%) & $354(60.8)$ & $318(57)$ & $304(55.1)$ & $290(50.3)$ & $310(54.1)$ & \\
Euro/year & 15.29 & 15.75 & 21.51 & 27.14 & 37.13 & \\
Euro/ day & 0.042 & 0.043 & 0.059 & 0.074 & 0.102 & $*$ \\
\% yearly increase & & 3 & 36.57 & 26.17 & 36.81 & ** \\
\% increase from baseline & & 3 & 40.68 & 77.5 & 142.84 & NS \\
\hline
\end{tabular}

**Significant at 5\% level; ***Significant at 1\%level; NS=Not significant; N=No. of women; 1Euro = 100 Tk 
Table 2 presents the data on household income from aquaculture where baseline was $60.8 \%$ which at the end of 2008-09, 2009-10, 2010-11 and 2011-12 were mounted to 57.0, 55.1, 50.3 and $54.1 \%$ respectively. The average yearly income became highly significantly increased ( $\mathrm{F}$ $=20.42$; P-value $<0.01$ ) from baseline BD Tk. 1529 (or 0.04 Euro/day) to 1575 (or 0.043
Euro/day), 2151 (or 0.059 Euro/ day), 2714 (0.074 Euro/ day) and 3713 (0.102 Euro/day) at the end of four years whereas yearly increased from baseline were reached to $3.00,40.68,77.5$ and $142.84 \%$ and, increasing from preceding years were significantly climbed $(\mathrm{t}=3.23$; $\mathrm{P}$ value $<0.05$ ) to $3.00,36.57,26.17$ and $36.81 \%$.

Table 3. Descriptive statistics of household income from homestead gardening

\begin{tabular}{lcccccc}
\hline & Base & $2008-09$ & $2009-10$ & $2010-11$ & $2011-12$ & P-value \\
\hline Mean & 670 & 1612 & 2333 & 2643 & 4465 & $* * *$ \\
N(\%) & $247(42.7)$ & $284(51.4)$ & $281(49)$ & $291(52.4)$ & $288(50.4)$ & \\
Euro/year & 6.7 & 16.12 & 23.33 & 26.43 & 44.65 & \\
Euro/day & 0.018 & 0.044 & 0.064 & 0.072 & 0.122 & \\
\%yearly increase & & 140.6 & 44.73 & 13.29 & 68.94 & NS \\
\%increase from baseline & & 140.6 & 248.21 & 294.48 & 566.42 & $* *$ \\
\hline
\end{tabular}

**Significant at 5\%level; ***Significant at 1\%level; NS=Not significant; N=No. of women; 1 Euro $=100 \mathrm{Tk}$

Table 3 renders the information about the household income for homestead gardening where the income getting beneficiaries increased from $42.7 \%$ to $51.4,49.0,52.4$ and 50.4 and, average yearly income became highly significantly increased $(\mathrm{F}=5.06$; $\mathrm{P}$-value $<0.01)$ from baseline BD Tk. 670 (or 0.018 Euro/ day) to 1612 (or 0.044 Euro/day), 2333 (or 0.064
Euro/day), 2643 (0.072 Euro/day) and 4465 (0.122 Euro/day) at the end of four years whereas yearly increased from baseline were significantly increased $(\mathrm{t}=3.45$; $\mathrm{P}$-value $<0.05$ ) to $140.60,248.21,294.48$ and $566.42 \%$ and, increasing from previous years were 140.60, 44.73, 13.29 and $68.94 \%$.

Table 4. Descriptive statistics of household total income from all three activities

\begin{tabular}{lcccccc}
\hline & Base & $2008-09$ & $2009-10$ & $2010-11$ & $2011-12$ & P-value \\
\hline Mean & 2800 & 4485 & 6434 & 7487 & 10690 & *** \\
N(\%) & $483(82.7)$ & $550(94.2)$ & $551(94.3)$ & $550(94.2)$ & $559(95.7)$ & \\
Euro/year & 28 & 44.85 & 64.34 & 74.87 & 106.9 \\
Euro/ day & 0.077 & 0.122 & 0.176 & 0.205 & 0.292 & \\
\%yearly increase & & 60.18 & 43.46 & 16.37 & 42.78 & $*$ \\
\%increase from baseline & & 60.18 & 129.79 & 167.39 & 281.79 & $* *$ \\
\hline
\end{tabular}

**Significant at 5\% level; ***Significant at 1\%level; NS=Not significant; N=No. of women; 1 Euro = 100 Tk

Table 4 gives the data on total household income from all three activities whereas, income getting beneficiaries increased from baseline $82.7 \%$ to 94.2, 94.3, 94.2 and 95.7 in the successive years. Average income, at individual level, highly significantly increased ( $\mathrm{F}=18.24$; $\mathrm{P}$-value $<0.01)$ from baseline BD Tk. 2800 (or 0.077 Euro/ day) to 4485 (or 0.122 Euro/ day), 6434 (or 0.176 Euro/day), 7487 (0.205 Euro/day) and 10690 (0.292 Euro/day) and, \% of yearly increasing income from baseline were significantly increased ( $\mathrm{t}=3.45$; $\mathrm{P}$-value $<0.05)$ to 60.18 , $129.79,167.39$ and $281.79 \%$ and, increasing $\%$ of income from preceding years were also significant $(\mathrm{t}=4.50$; $\mathrm{P}$-value $<0.05)$ reached to $60.18,43.46,16.37$ and $42.78 \%$.

\section{Discussion}

From this study, it was evident that, integrated small-scale agriculture is a tool to improve the socioeconomic and food security status of women and hence empowered them in their family and society. Number of women getting income from small-scale agriculture increased in successive years and income of individual beneficiaries increased significantly from baseline. As there was increasing production in three sectors, there were availability of vegetables, fish and poultry meat in the household which is in agreement with the statement of DFID (2004) stated as agricultural development is a tool in reducing poverty and improving food security in this areas. Further more, integrated crops, livestock, and aquaculture can be used for potential yield improvements and monetary advantages as well as positive implications for food security, dietary balance, and nutrition (Uddin and Takeya, 2006). In addition, it was stated that family poultry specially acts as an income source and employment of women (Gujit, 1994; Fattah, 2000; Islam et al., 2014). To sum up, family income became increased from selling of vegetables, fish and poultry, nutrition security increased through household production, and unemployment will be reduced through the selfemployment. 


\section{Acknowledgment}

The project was sponsored by ICCO and NUTRECO, The Netherlands, conducted by SLOPB-Bangladesh, and the study was framed by Department of Food Microbiology, PSTU, Bangladesh.

\section{References}

DFID. 2004. Agriculture, growth and poverty reduction. p.21.

Fattah, K.A. 2000. Poultry as a tool in poverty eradication and promotion of gender equality. In: F. Dolberg \& P.H. Petersen (Eds.), proceedings of a workshop on poultry as a tool in poverty eradication and promotion of gender equality. Tune, Denmark. pp. 16-28.

Gujit, I. 1994. Making a difference: integrating gender analysis into PRA training. Rapid Rural Appraisal Notes No. 19, Special Issue on Training, Sustainable Agriculture Programme, International Institute for Environment and Development. pp. 49-55.

Hossain, M. 2004. Poverty alleviation through agriculture and rural development in Bangladesh, CPD occational paper 39, pp. 116.
Islam, M.N., Islam, S., Salam, M.A., Tapu, M.A.I., Khan, M.S.I. and Begum, M.R. 2014. Family poultry for poverty alleviation and gender equality promotion in coastal Bangladesh: a food and nutritional security study. J. Agril. Sci. 6(6): 30-34.

Maxwell, S. 2001. WDR 2000: Is there a "new poverty agenda"? Dev. Policy Rev. 19(1): 143- 149.

Sen, B. 2001. "Rethinking anti-poverty" in changes and challenges. A Review of Bangladesh's Development 2000. Centre for Policy Dialogue and University Press Ltd., Dhaka. pp. 115-160.

Uddin, M.T. and Takeya, H. 2006. Comparative study on integrated farming in Bangladesh and other countries. Bangladesh J. Agril. Econs. 29(1/2): 81-92.

Warr, P. 2001. Poverty reduction and sectoral growth, results from South East Asia. Australia National University: Canberra, Australia. p.11.

World Bank, 2002. Poverty in Bangladesh: Building on progress, poverty reduction and economic management sector unit, South Asia region, World Bank, Washington, D.C., Report No. 24299-BD. 